\title{
PRODUCERS' AND CONSUMERS' ATTITUDES TOWARDS FROZEN VEGETABLES IN THE SOUTH AFRICAN RETAIL MARKET: A COMPARATIVE STUDY
}

\author{
P J DU PLESSIS \\ Graduate School of Business Leadership \\ University of South Africa
}

B R HATCHER

Epol Foods

C BOSHOFF

University of Otago,

Dunedin, New Zealand

\begin{abstract}
OPSOMMING
Die doelwitte met hierdie studie is om die verskillende houdings tussen verbruikers en produsente van gevriesde groente te ondersoek en om te bepaal of inkome van respondente ' $n$ invloed uitoefen op sodanige houdings. 'n Verdere doelwit is om vas te stel hoe die produkattribute van beide vars en gevriesde groente deur verbruikers waargeneem word. Resultate dui daarop dat produsente van gevriesde groente beduidend meer positief teenoor gevriesde groente is as verbruikers. Inkomstevlakke beïnvloed nie die verbruikers se houdings teenoor vars en gevriesde groente nie en dit suggereer dat inkome nie as 'n segmentasieveranderlike gebruik behoort te word nie. Daar is ook bevind dat verbruikers se houdings teenoor vars en gevriesde groente beduidend verskil.
\end{abstract}

\begin{abstract}
The objectives of this study are to investigate the attitudes between consumers and producers of frozen vegetables and to determine whether income of respondents exert an influence on their attitudes towards frozen vegetables. A further objective is to establish how the product attributes in respect of both fresh and frozen vegetables are perceived by consumers. Results indicate that producers of frozen vegetables are significantly more positive towards frozen vegetables than consumers. Income level does not influence consumers' attitudes towards frozen vegetables, and it suggests that income should not be used as a segmentation variable. It was also found that consumers attitudes towards fresh and frozen vegetables differ significantly.
\end{abstract}

\section{INTRODUCTION}

The philosophy of the marketing concept contends that business firms who succeed in satisfying consumer needs better than competitors are more likely to achieve the goals of the organisation (Kotler, 1991.)

Consumers frequently do not fully understand in advance all the ways in which a product might provide value (Porter, 1985). This incomplete knowledge regarding value presents the seller with the opportunity to educate buyers about the differentiating attributes.

The frozen vegetable industry in South Africa has been stagnating and constitutes less than four per cent of national consumption (Hatcher, 1991). Given the relative low cost of the fresh product, the strategy of the frozen industry has always been one of differentiation. In a case such as that between frozen and fresh vegetables, where the differentiation strategy delivers less than modest value, the educational process assumes greater importance (Porter, 1985, and Thompson \& Strickland, 1987).

Consumers develop attitudes about a product based largely on that product's attributes or signals of value. Adequately signalling a product value can often be as important as the product value actually delivered.

*Requests for reprints should be addressed to P J du Plessis, Graduate School of Business Leadership, UNISA, P.O. Box 392, Pretoria 0001

\section{CONSUMER ATTITUDES AND CONSUMER DECISION-MAKING}

Attitudes towards a product or service are important elements in a consumer's decision-making process and consumer attitudes are probably the most considered concept in the study of consumer behaviour (Du Plessis, Rousseau and Blem, 1990). During the process of attitude formation towards a specific product, the cues and signals of value regarding that product's attributes are of paramount importance. When a positive attitude towards a product exists the likelihood of a person buying the product is favourable (Fishbein and Ajzen, 1975).

Satisfaction with a product may lead a consumer to buy a product again and foster a positive attitude towards the product.

Products or services should provide value to a consumer but consumers frequently do not fully understand in advance all the ways in which a product might provide value. Inadequate knowiedge regarding value presents the seller with the opportunity to educate buyers about differentiating features and endeavour to change their attitudes towards products.

In this study the attitudes of consumers towards frozen vegetables are investigated and compared to that of producers of frozen vegetables.

No published research findings of similar studies with regard to the vegetable market could be located: both national and 
international. This study can thus be regarded as exploratory research.

The model selected for measurement of the attitudes of the target groups was the tri-component model. In this model, attitude has been segmented into the components of cognition, conation and affect. Per definition the cognitive component refers to a person's belief or cognitions about the attitude object. The affective component is concerned with the consumers' like or dislike of the attitude object while the conative or behavioural part refers to a person's action or behaviour tendencies (Engel, Blackwell \& Miniard, 1986). There is virtual unanimity among theorists concerning the existence of these components (Sheth, 1974; Chisnall, 1985; Berkman \& Gilson, 1986; Weiers, 1988; Du Plessis et al., 1990). The inclusion of cognition and affection in the structure of the model was important for this research because consumer information acquisition and decision-making processes differ, depending on whether the motive behind involvement is cognitive of affective (Zaltman and Wallendorf, 1983). Attitudes towards 12 product attributes of frozen vegetables were examined. These attitudes were linked to the tri-component model's components of cognition, conation and affect.

\section{CHARACTERISTICS OF THE FROZEN VEGETABLE MARKET}

Vegetables are marketed to South African consumers in four forms, namely fresh, frozen, canned and dehydrated vegetables. Of these, fresh vegetables account for $95,4 \%$ of the market, followed by frozen vegetables $2,1 \%$, canned vegetables $1,4 \%$ and dehydrated vegetables $1,1 \%$. The $95 \%$ market share of fresh vegetables represents 2000 tons of fresh produce consumed annually. The actual size of the frozen vegetable market was approximately 25 thousand tons in 1985, increased marginally annually to reach about 30 thousand tons in 1989 but then declined again to 28 thousand and 29 thousand tons in 1990 and 1991 respectively (Hatcher, 1991).

These figures suggest that the frozen vegetable market (the focus of this study) has largely stagnated.

A possible explanation for the stagnation is that the frozen vegetable market is an oligopolistic market (three large producers account for $99 \%$ of annual output) in which it appears that major producers have done little to expand the frozen vegetable market. In addition, high barriers to entry, notably high capital requirements and limited scope to realise economies of scale benefits, could have resulted in a degree of insensitivity to consumer needs among producers of frozen vegetables. This contention of market insensitivity due to the absence of substantial new competitors entering the market, is the point of departure of this study.

\section{PRODUCT CHARACTERISTICS}

The product characteristics considered in this study are convenience of preparation, wastage due either to degradation over time or inedible portions of the product (eg cauliflower leaves), vitamin content, preservatives used, cost, cooking time required, taste, health/nutritional value, seasonality and freshness.

\section{OBJECTIVES OF THE STUDY}

The overall purpose of this research is to identify the attitudes of a specific group of producers of frozen vegetables and consumers towards fresh and frozen vegetables. For the purpose of this study a discrepancy between the attitudes of consumers and the attitudes of the producers of frozen vegetables will be regarded as a surrogate measure of the failure of producers to satisfy market needs. A poor understanding of consumer needs is believed to have contributed to the stagnation of sales of frozen vegetables in the consumer market despite the fact that frozen vegetables sales constitute less than $4 \%$ of the market.
A second broad objective of the study is to investigate how various product attributes in respect of both fresh and frozen vegetables are perceived by consumers. A discrepancy in attitudes will indicate that the producers of frozen vegetables have not been able to successfully differentiate their products from those offered by competitors - in this case the producers of fresh vegetables.

A third objective is to determine whether the income of respondents exert an influence on their attitudes towards frozen vegetables. As frozen vegetables can be up to ten times more expensive than fresh vegetables, it may be surmised that only upper income consumers will be positively inclined towards frozen vegetables due to its relatively high cost.

In more specific terms, the objectives of this study are:

- to establish whether the income levels of consumers influence their attitude towards frozen vegetables;

- to establish whether consumers perceive various product attributes of vegetables differently when comparing fresh and frozen vegetables; and

- to compare the attitudes of producers of frozen vegetables with those of consumers.

To address those objectives, the following hypotheses were tested

$\mathrm{HO}_{1}$ : There is no relationship between high level of income and high level of consumption of frozen vegetables.

$\mathrm{HO}_{2}$ : There is no relationship between level of income and the attitudes of consumers towards frozen vegetables.

$\mathrm{HO}_{3}$ : There is no significant difference between consumer attitudes towards frozen vegetables and fresh vegetables, in terms of the individual product attributes.

$\mathrm{HO}_{4}$ : There are no significant differences between producer and consumer attitudes towards frozen vegetables.

$\mathrm{HO}_{5}$ : There are no significant differences between attitudes of producers and attitudes of consumers towards fresh vegetables.

\section{METHODOLOGY}

This study compares consumer attitudes towards frozen and fresh vegetables within the South African retail market. It was assumed that all persons consume fresh vegetables. However, for a consumer to be able to respond adequately to questions regarding frozen vegetables, exposure to the purchase of this product was a logical prerequisite. Accordingly, the target population was defined as all persons of 18 years or more, who purchase, or who have purchased, frozen vegetables at any retail outlet in South Africa.

Over 93 per cent of frozen vegetable sales occur in supermarket and hypermarket retail outlets and approximately 85 per cent of estimated fresh vegetable sales occur within 14 municipal areas within South Africa.

Against this background it was decided to conduct personal interviews with consumers in selected supermarkets within 14 municipal areas in South Africa, namely: PWV (7 areas), Cape Town, Durban, Pietermaritzburg, Port Elizabeth, East London, Kimberley and Welkom.

Ideally, an individual respondent would be a buyer who shops within supermarkets or hypermarkets located within these 14 largest municipal areas. Within these strata, elements could be individually identified through their action of removing frozen vegetables from the shelves in the designated stores.

Data collection from two samples (consumers of frozen vegetables $(n=543)$ and producers of frozen vegetables $(n=18)$ occurred by means of personal interviews based on a structured questionnaire. The interviews with consumers were conducted by members of the Housewives' League of South Africa in designated large retail outlets throughout South Africa. Written, personal and telephonic explanations as well as training 
were given to interviewers of the relevant branches of the Housewives' League. Once a purchaser of frozen vegetables removed the product from the shelf, he/she was approached and requested to participate in the study.

One additional refinement was an attempt to approximate a proportionate stratification. Based on the sales of fresh vegetables by municipal region, these "proportions" were replicated in the number of interviews conducted in that region. In effect, the distribution of questionnaires to each municipal region was proportional to the sales of fresh vegetables in that region. The procedure culminated in 543 respondents taking part in the study. Of the respondents approached, $36 \%$ earned less than R30 000 per year, 38\% between R30 000 and R60 000 and $19 \%$ more than R60 000 per year (7\% non-response).

A similar questionnaire was used to assess the attitudes of the producers of frozen vegetables. Of the 25 senior executive managers within the industry, 18 were personally interviewed.

\section{RESULTS}

To determine whether consumers with varying levels of income perceived fresh and frozen vegetables differently in terms of 12 identified product attributes, respondents were asked to rate each product on a 5-point semantic differential scale. The mean values of individual attribute ratings for three income groups (high, medium and low) were compared by means of an analysis of variance (ANOVA).

TABLE 1

ANOVA ON FROZEN VEGETABLE ATTRIBUTES

\begin{tabular}{|c|c|c|c|c|c|}
\hline \multirow{3}{*}{$\begin{array}{c}\text { PRODUCT } \\
\text { ATTRIBUTE } \\
\text { (DEPENDENT } \\
\text { VARIABLE) }\end{array}$} & \multirow{3}{*}{$\begin{array}{c}\text { SIGNIFICANCE } \\
\text { OF } \\
\text { ANOVA }\end{array}$} & \multicolumn{3}{|c|}{ INCOME } & \multirow{3}{*}{$\begin{array}{c}\text { RESULTS } \\
\text { OF } \\
\text { SCHEFFE'S } \\
\text { TEST }\end{array}$} \\
\hline & & LOW & MIDDLE & $\mathrm{HIGH}$ & \\
\hline & & $\begin{array}{l}\text { MEAN OF } \\
\text { GROUP } 1\end{array}$ & $\begin{array}{l}\text { MEAN OF } \\
\text { GROUP } 2\end{array}$ & $\begin{array}{l}\text { MEAN OF } \\
\text { GROUP } 3\end{array}$ & \\
\hline WASTAGE & NS & 4,613 & 4,556 & 4,495 & NONE \\
\hline VITAMINS & $* *$ & 3,844 & 3,815 & 3,516 & $2-3$ \\
\hline PRESERVATIVES & NS & 4,134 & 3,955 & 3,903 & NONE \\
\hline PRICE & NS & 2,567 & 2,441 & 2,290 & NONE \\
\hline COOK TIME & NS & 4,484 & 4,473 & 4,416 & NONE \\
\hline AVAILABILITY & NS & 4,425 & 4,393 & 4,376 & NONE \\
\hline CONVENIENCE & ** & 4,528 & 4,699 & 4,710 & NONE \\
\hline QUALITY & * & 3,995 & 3,927 & 3,720 & NONE \\
\hline TASTE & ** & 3,713 & 3,747 & 3,355 & $1-3 \& 2-4$ \\
\hline HEALTHY & NS & 3,972 & 4,011 & 3,796 & NONE \\
\hline LUXURY & NS & 3,219 & 3,118 & 2,968 & NONE \\
\hline FRESHNESS & $* *$ & 4,006 & 4,134 & 3,731 & $2-3$ \\
\hline
\end{tabular}

${ }^{*} \mathrm{p}<0,1$

** $p<0,05$

$\star \star \star *<<0,01$

Table 1 shows that the three income groups rate 5 of the 12 individual product attributes significantly different - vitamin content, convenience, taste and freshness at the $5 \%$ level, and quality at the $1 \%$ level of significance. The ANOVA procedure only identifies the individual attributes in respect of which significant differences occurred. It does not indicate between which of the three income groups the difference actually exists. For this reason a Scheffe's multiple comparison procedure was used. The results, shown in Table 1 reveal that in respect of vitamins, taste and freshness of produce, significant differences exist between the high and the middle income group (group 2). The middle income group rates the attribute significantly higher than do the lower income group.

Hypothesis $1\left(\mathrm{HO}_{1}\right)$ cannot be accepted in respect of the product attributes vitamins, taste and freshness.

In addition Table 1 also shows that in respect of 11 of the 12 product attributes considered, the mean evaluations of the high income group is the lowest. These low ratings seem to suggest a relatively poor image of frozen vegetables among consumers in the high income group.

When the overall ratings of respondents (rather than for individual attributes) were considered by means of a MANO$\mathrm{VA}$, no significant difference between the three income groups emerged (Table 2).

TABLE 2 MANOVA TEST RESULTS

\begin{tabular}{lccccc}
\hline \multicolumn{1}{c}{ STATISTIC } & VALUE & F & $\begin{array}{c}\text { DF } \\
\text { NUMERATOR }\end{array}$ & $\begin{array}{c}\text { DF } \\
\text { DENOMINATOR }\end{array}$ & PR > F \\
\hline WILKS' LAMBDA & 0,9345 & 1,2711 & 24 & 886 & 0,1730 \\
PILLAI'S TRACE & 0,0664 & 1,2712 & 24 & 888 & 0,1729 \\
HOTELLING - & 0,06902 & 1,2711 & 24 & 884 & 0,1730 \\
LAWLEY TRACE & & & & & \\
ROY'S GREATEST & 0,0470 & 1,7404 & 12 & 444 & 0,0560 \\
ROOT & & & & & \\
\hline
\end{tabular}

NOTE: F Statistic for Roy's Greatest root is an upper bound.

F Statistic for Wilks' Lambda is exact.

The null hypothesis $\left(\mathrm{HO}_{2}\right)$ cannot be rejected, suggesting that income level may be an inappropriate segmentation variable for consumer attitudes towards frozen vegetables.

A third hypothesis addressed in this study was that consumers do not perceive frozen and fresh vegetables to perform differently in respect of the 12 product attributes investigated. Respondents were asked to rate both frozen and fresh vegetables on a 5-point semantic differential scale. A difference-score between the ratings of the product was then calculated, which implied maximum difference scores of +4 and -4 .

The difference-scores per individual item were then subjected to a t-test to consider whether differences for individual items were statistically significant.

TABLE 3

ANOVA ON CONSUMER ATTITUDES TOWARDS FRESH AND FROZEN VEGETABLES

\begin{tabular}{lccccc}
\hline \multicolumn{1}{c}{ ATTRIBUTE } & MEAN & STANDARD & $t$ & PROB $>$ (t) & SIGNIFICANCE \\
\hline \multicolumn{1}{c}{1} & \multicolumn{1}{c}{2} & 3 & \multicolumn{1}{c}{4} & 5 & 6 \\
\hline AVAILABILITY & 2,0653 & 0,0766 & 26,9498 & 0,000 & $* * *$ \\
CONVENIENCE & 1,6922 & 0,0726 & 23,3043 & 0,001 & $* * *$ \\
WASTAGE & 1,5417 & 7,0708 & 21,789 & 0,001 & $* * *$ \\
COOKING TIME & 1,3705 & 0,0728 & 18,8246 & 0,001 & $* * *$ \\
FRESHNESS & 0,1784 & 0,0747 & 2,3889 & 0,0173 & $* *$ \\
QUALITY & 0,1098 & 0,0679 & 1,6168 & 0,1066 & $N S$ \\
PRESERVATIVES & $-0,4392$ & 0,0737 & $-5,9579$ & 0,0001 & $* * *$ \\
PRICE & $-0,8419$ & 0,0798 & $-10,556$ & 0,0001 & $* * *$ \\
TASTE & $-0,6627$ & 0,0626 & $-10,579$ & 0,0001 & $* * *$ \\
VITAMINS & $-0,7089$ & 0,0587 & $-12,068$ & 0,0001 & $* * *$ \\
LUXURY & $-1,1593$ & 0,0896 & $-12,934$ & 0,000 & $* * *$ \\
HEALTHY & $-0,7249$ & 0,0550 & $-13,175$ & 0,0001 & $* * *$ \\
FEEL DIFF & $-0,0506$ & 0,0488 & 11,038 & 0,2999 & $N S$ \\
KNOW DIFF & 0,4645 & 0,0404 & 11,502 & 0,0001 & $* * *$ \\
\hline
\end{tabular}

${ }^{* *} \mathrm{p}<0,05$

$* * * \mathrm{p}<0,01$

Table 3 shows that when evaluations of individual product attributes are considered, significant differences exist between attitudes towards frozen and fresh vegetables in respect of 10 of the 12 product attributes at the $1 \%$ level. In respect of freshness a significant difference at the $5 \%$ level was recorded. Attitudes about the quality of the two products do not differ significantly.

Hypothesis $3\left(\mathrm{HO}_{3}\right)$ cannot be accepted in respect of 11 of the 12 attributes considered. 
A further objective of this study was to consider whether attitudes of consumers and producers of frozen vegetables differ in respect of frozen and fresh vegetables. Table 4 reflects the comparison, by means of a t-test, of these attitudes towards frozen vegetables.

\section{TABLE 4}

CONSUMER AND PRODUCER ATTITUDES TOWARDS FROZEN VEGETABLES

\begin{tabular}{|c|c|c|c|c|c|c|c|}
\hline $\begin{array}{l}\text { PRODUCT } \\
\text { ATTRIBUTE }\end{array}$ & RESPONDENT & $\mathrm{N}$ & MEAN & $\begin{array}{l}\text { STD. } \\
\text { DEV. }\end{array}$ & $t$ & DF & $\begin{array}{l}\text { SIGNIFI- } \\
\text { CANCE }\end{array}$ \\
\hline WASTAGE & & $\begin{array}{r}517 \\
18\end{array}$ & $\begin{array}{l}4,57 \\
4,83\end{array}$ & $\begin{array}{l}0,919 \\
0,383\end{array}$ & $-2,63$ & 24,5 & $\star \star$ \\
\hline VITAMINS & $\begin{array}{l}\text { CONSUMER } \\
\text { PRODUCER }\end{array}$ & $\begin{array}{r}519 \\
18\end{array}$ & $\begin{array}{l}3,74 \\
3,94\end{array}$ & $\begin{array}{l}1,084 \\
0,938\end{array}$ & $-0,89$ & 18,6 & NS \\
\hline $\begin{array}{l}\text { PRESERVA- } \\
\text { TIVES }\end{array}$ & & $\begin{array}{r}504 \\
18\end{array}$ & $\begin{array}{l}3,99 \\
4,83\end{array}$ & $\begin{array}{l}1,29 \\
0,514\end{array}$ & $-6,28$ & 25,4 & $\star \star \star$ \\
\hline PRICE & $\begin{array}{l}\text { CONSUMER } \\
\text { PRODUCER }\end{array}$ & $\begin{array}{r}520 \\
18\end{array}$ & $\begin{array}{l}2,49 \\
2,11\end{array}$ & $\begin{array}{l}1,33 \\
2,11\end{array}$ & $\begin{array}{l}1,63 \\
0,96\end{array}$ & 19,3 & NS \\
\hline $\begin{array}{l}\text { COOKING } \\
\text { TIME }\end{array}$ & & $\begin{array}{r}521 \\
18\end{array}$ & $\begin{array}{l}4,46 \\
4,44\end{array}$ & $\begin{array}{l}0,980 \\
0,705\end{array}$ & 0,09 & 19,3 & NS \\
\hline AVAILABILITY & CONSUMER & 519 & 4,41 & 1,013 & $-5,44$ & 30,4 & $\star \star \star \star ~$ \\
\hline $\begin{array}{l}\text { CONVE- } \\
\text { NIENCE }\end{array}$ & $\begin{array}{l}\text { CONSUMER } \\
\text { PRODUCER }\end{array}$ & $\begin{array}{r}528 \\
18\end{array}$ & $\begin{array}{l}4,64 \\
4,88\end{array}$ & $\begin{array}{l}0,727 \\
0,323\end{array}$ & $-3,06$ & 23,3 & $\star * *$ \\
\hline QUALITY & $\begin{array}{l}\text { CONSUMER } \\
\text { PRODUCER }\end{array}$ & $\begin{array}{r}517 \\
18\end{array}$ & $\begin{array}{l}3,89 \\
4,00\end{array}$ & $\begin{array}{l}0,994 \\
0,594\end{array}$ & $-0,76$ & 20,5 & NS \\
\hline TASTE & $\begin{array}{l}\text { CONSUMER } \\
\text { PRODUCER }\end{array}$ & $\begin{array}{r}519 \\
18\end{array}$ & $\begin{array}{l}3,67 \\
4,00\end{array}$ & $\begin{array}{l}1,103 \\
0,594\end{array}$ & $-2,21$ & 21,3 & ** \\
\hline HEALTHY & $\begin{array}{l}\text { CONSUMER } \\
\text { PRODUCER }\end{array}$ & $\begin{array}{r}513 \\
18\end{array}$ & $\begin{array}{l}3,95 \\
4,55\end{array}$ & $\begin{array}{l}1,043 \\
0,511\end{array}$ & $-4,73$ & 22,3 & $* * *$ \\
\hline LUXURY & $\begin{array}{l}\text { CONSUMER } \\
\text { PRODUCER }\end{array}$ & $\begin{array}{r}514 \\
18\end{array}$ & $\begin{array}{l}3,12 \\
2,83\end{array}$ & $\begin{array}{l}1,511 \\
0,857\end{array}$ & 1,36 & 20,9 & NS \\
\hline FRESHNESS & $\begin{array}{l}\text { CONSUMER } \\
\text { PRODUCER }\end{array}$ & $\begin{array}{r}512 \\
18\end{array}$ & $\begin{array}{l}3,97 \\
3,88\end{array}$ & $\begin{array}{l}1,171 \\
0,832\end{array}$ & 0,42 & 19,4 & NS \\
\hline
\end{tabular}

${ }^{\star *} p<0.05$

$* * * p<0.01$

Table 4 reveals that significant differences in attitudes between consumers and producers exist in respect of six of the 12 product attributes considered. Differences exist in respect of wastage and taste at the $5 \%$ level of significance, and in respect of preservatives, availability, convenience and health at the $1 \%$ level. In all instances producer attitudes towards the individual attribute are more favourable than those of consumers. However, in many instances there should be no difference in attitudes between consumer and producer; for example, neither fresh nor frozen vegetables contain preservatives, and as such attitudes should not vary between fresh and frozen vegetables, nor indeed between producer and consumer.

Hypothesis $4\left(\mathrm{HO}_{4}\right)$ cannot therefore be accepted in respect of those six attributes.

The results of both samples suggest that frozen vegetables are more expensive than fresh vegetables. A similar comparison was conducted to compare the attitudes of consumers and producers towards fresh vegetables and is presented in Table 5.

The results, summarised in Table 5 indicate that differences exist in terms of eight of the 12 product attributes considered. The difference in respect of luxury is at the $10 \%$ level of significance, vitamins, cooking time, availability and freshness at the $5 \%$ level; and wastage, convenience and quality at the $1 \%$ level. In all instances, except for price, the attitudes of fresh vegetables among producers of frozen vegetables are less favourable than those of consumers.

Hypothesis $5\left(\mathrm{HO}_{5}\right)$ cannot be accepted in respect of those attitudes. Consumers thus perceive fresh vegetables in a more favourable light than do the producers of frozen vegetables.
TABLE 5

CONSUMER AND PRODUCER ATTITUDES TOWARDS FRESH VEGETABLES

\begin{tabular}{|c|c|c|c|c|c|c|c|c|}
\hline $\begin{array}{c}\text { ATTITUDE } \\
\text { COMPONENT }\end{array}$ & $\begin{array}{l}\text { PRODUCT } \\
\text { ATTRIBUTE }\end{array}$ & R & $\mathrm{N}$ & $\mathrm{ME}$ & $\begin{array}{l}\text { STD. } \\
\text { DEV. }\end{array}$ & $t$ & DF & $\begin{array}{l}\text { SIGNIFI- } \\
\text { CANCE }\end{array}$ \\
\hline $\mathrm{COG}$ & WA & & $\begin{array}{r}516 \\
18\end{array}$ & $\begin{array}{l}3,04 \\
1,89\end{array}$ & $\begin{array}{l}1,280 \\
0,758\end{array}$ & 6,19 & 20,5 & $\star \star \star$ \\
\hline COGI & VITAMINS & & $\begin{array}{r}524 \\
18\end{array}$ & $\begin{array}{l}4,45 \\
3,83\end{array}$ & $\begin{array}{l}0,929 \\
0,924\end{array}$ & 2,8 & 18,2 & $\star *$ \\
\hline COGI & $\begin{array}{l}\text { PRESERVA- } \\
\text { TIVES }\end{array}$ & & $\begin{array}{r}507 \\
18\end{array}$ & $\begin{array}{l}4,46 \\
4,67\end{array}$ & $\begin{array}{l}1,240 \\
0,970\end{array}$ & & 19,0 & NS \\
\hline COG & PRICE & & $\begin{array}{r}520 \\
18\end{array}$ & $\begin{array}{l}3,30 \\
3,39\end{array}$ & $\begin{array}{l}1,203 \\
0,698\end{array}$ & $-0,50$ & 20,7 & NS \\
\hline COGI & $\begin{array}{l}\text { COOKING } \\
\text { TIME }\end{array}$ & & $\begin{array}{r}519 \\
18\end{array}$ & $\begin{array}{l}3,11 \\
2,44\end{array}$ & $\begin{array}{l}1,218 \\
1,042\end{array}$ & 2,65 & 18,6 & $* *$ \\
\hline $\mathrm{COGI}$ & $\begin{array}{l}\text { AVAILA- } \\
\text { BILITY }\end{array}$ & & $\begin{array}{r}523 \\
18\end{array}$ & $\begin{array}{l}2,36 \\
1,67\end{array}$ & $\begin{array}{l}1,356 \\
1,085\end{array}$ & 2,64 & 18,9 & $* *$ \\
\hline AFFE & & & $\begin{array}{r}522 \\
18\end{array}$ & $\begin{array}{l}2,95 \\
2,39\end{array}$ & $\begin{array}{l}1,401 \\
0,698\end{array}$ & 3,20 & 22,0 & $\star \star \star *$ \\
\hline AFFE & QUALITY & & $\begin{array}{r}517 \\
18\end{array}$ & $\begin{array}{l}3,74 \\
3,06\end{array}$ & $\begin{array}{l}1,137 \\
0,539\end{array}$ & 5,03 & 22,6 & $\star \star \star \star$ \\
\hline $\mathrm{AFF}$ & & & $\begin{array}{r}521 \\
18\end{array}$ & $\begin{array}{l}4,32 \\
4,11\end{array}$ & $\begin{array}{l}1,004 \\
0,676\end{array}$ & 8 & 19,7 & \\
\hline $\mathrm{N}$ & HEA & $\begin{array}{l}\text { CON } \\
\text { PROL }\end{array}$ & $\begin{array}{r}517 \\
18\end{array}$ & $\begin{array}{l}4,66 \\
4,61\end{array}$ & $\begin{array}{l}0,780 \\
0,608\end{array}$ & 0,33 & 19,0 & NONE \\
\hline AFFEC & LUXURY & $\begin{array}{l}\text { UMER } \\
\text { JCER }\end{array}$ & $\begin{array}{r}511 \\
18\end{array}$ & $\begin{array}{l}4,27 \\
3,94\end{array}$ & $\begin{array}{l}1,121 \\
0,725\end{array}$ & 1,83 & 20,0 & * \\
\hline AFFE & $\begin{array}{l}\text { FRESH- } \\
\text { NESS }\end{array}$ & $\begin{array}{l}\text { CONSUMER } \\
\text { PRODUCER }\end{array}$ & $\begin{array}{r}514 \\
18 \\
\end{array}$ & $\begin{array}{l}3,79 \\
3,22\end{array}$ & $\begin{array}{l}1,146 \\
1,003\end{array}$ & 2,35 & 18,6 & $\star *$ \\
\hline
\end{tabular}

* $\mathrm{p}<0,1$

$* * \mathrm{p}<0,05$

$\star \star \star \mathrm{p}<0,01$

\section{DISCUSSION OF RESULTS}

\section{Managerial Implications}

Positioning exerts an important influence on consumer choice by distinguishing products and services from competing offers. It is based on the acceptance that different market segments have different needs and are therefore attracted to different offers (Kotler, 1991. Positioning is thus what the marketer, in the words of Trout and Ries (1979), does to the mind of the prospect by emphasising differentiations features.

The positioning strategy, according to Kotler (1991), serves as a guideline for the entire marketing mix. Once a clear position has been decided on, each element of the marketing mix should then contribute towards establishing or enhancing the firm, product or service's position. As could be expected, the marketing communication strategy plays a particularly important role in positioning (Aaker and Myers, 1987).

The results of this study have shown that marketing communication and positioning are two areas in which the marketers of frozen vegetables have been less than successful. The true value of the product is not brought home to consumers, resulting in poor or ineffectual differentiation and positioning. Unless the marketers of frozen vegetables can successfully convince consumers of the true value of their product through, among others, communication, the desired differentiation from competitors such as fresh vegetables will not materialise.

There are also strong indications that the use of level of income as a segmentation variable may be inappropriate. Table 1, for instance, shows that higher income consumers (the market segment targeted traditionally by the marketers of frozen vegetables) report a particularly poor attitude towards frozen vegetables. The relatively poor ratings suggest that income may be an inappropriate segmentation variable for frozen vegetables (see Table 2). 
The conclusion that producers of frozen vegetables report significantly different attitudes towards both frozen and fresh vegetables than consumers suggest that management is not aware of consumer needs. Especially the tendency among producers to rate frozen vegetables (a market they are expected to know well) more favourably than consumers in terms of six of twelve attributes considered, is cause for concern. This discrepancy will only be eliminated through effective market research.

\section{Theoretical Implication}

For certain items on the questionnaire, the use of a Likert scale might have been preferable to the semantic differential scale. In similar fashion it could be argued that the occasional use of a ratio scale in the place of the semantic differential scale has merit. The use of the tricomponent model proved to be valuable and practical.

The finding that producers of frozen vegetables are significantly more positively inclined towards frozen vegetables than consumers in respect of six of the 12 attributes investigated, reveals that producers do not fully appreciate consumer needs. This contention is confirmed when one considers that consumer attitudes towards fresh vegetables are considerably more favourable than those of the producers of frozen vegetables.

\section{SUMMARY}

This study suggests and it is surmised that the producers of frozen vegetables may have used inappropriate segmentation variables and targeted incorrect market segments in the past. In addition they have failed to effectively signal the value of their products, and thus have not differentiated their products from those of their major competitors - fresh vegetables. Both these considerations may have contributed to the absence of sales growth in the frozen vegetable market in the recent past. Efforts to break the impasse will have to be centre on a rethink of the current market segmentation, targeting and positioning strategies in general, and in the manner in which product value is signalled in particular.

Although every possible effort was made to eliminate the possible influence of interviewer bias through proper training and field controls, the possibility that interviewers influenced responses cannot be totally discounted. It is believed however, that the advantages of using fieldworkers who know the retail market well and who are used to interacting with the public, far outweighed possible disadvantages.
The fact that 87 per cent of the respondents came from a single race group precluded the identification of attitudes of different groups. Respondents from particular groups who were approached, proved incapable of answering certain items on frozen vegetables. The inability of large sections of the South African population to answer questions or complete questionnaires indicates that special procedures will be required for attempts to change attitudes and gauge the extent of change.

\section{REFERENCES}

Aaker, D.A. and Myers, J.G. (1987). Advertising management. Third edition. Englewood Cliffs, New Jersey: Prentice-Hall.

Chisnall, M.P. (1985). Marketing: a behavioral analysis. Second edition. London: McGraw-Hill.

Berkman, H.W. and Gilson, C. (1986). Consumer behavior: concepts and strategies. Third Edition. Boston: Kent Publishers.

Du Plessis, P.J., Rousseau, G.G. and Blem, N.H. (1990). Consumer behavior: a South African Perspective. Johannesburg: Southern Publishers.

Engel, J.F., Blackwell, R.D. and Miniard, P.W. (1986). Consumer behavior. Fifth edition. Chichago: The Dryden Press.

Fishbein, M. and Ajzen I., (1975). Belief, attitude, intention and behavior: an introduction to theory and research. Reading, Massachusetts: Addison - Wesley.

Hatcher, B.R. (1991). A comparison of producers', and consumers' attitudes towards frozen vegetables in the South African retail market. Unpublished MBL research report. Pretoria: University of South Africa.

Kotler, P. (1991). Marketing management: analysis, planning, implementation and control. Seventh edition. Englewood Cliffs, New Jersey: Prentice-Hall.

Porter, M.E. (1985). Competitive advantage. New York: Free Press.

Sheth, J.N. (Ed.) (1974). Models of buyer behavior. New York: Harper and Row.

Thompson, A.A. and Strickland, A.J. (1987). Strategic management: concepts and cases. Fourth Edition. Texas: Business Publications.

Trout, J. and Ries, A. (1979). The positioning era: a view ten years later. Advertising Age, July, 39-42.

Weiers, M.R. (1988). Marketing research. Second edition. Englewood Cliffs, New Jersey: Prentice-Hall.

Zaltman, G. and Wallendorf, M. (1983). Consumer behaviour: basic findings and management implications. Second edition. New York: John Wiley \& Sons. 